[The role of the Greek Catholic Church and its clergy in the formation and activity of civil society structures in Galicia (XIX-XX centuries)]. Istorychni studii Skhidnoievropeiskoho natsionalnoho universytetu imeni Lesi Ukrainky. Lutsk. Vyp. 11-12, 24-30.

7. Svoboda. № 3. 1893.

8. Svoboda. № 4. 1893.

9. Svoboda. № 6. 1893.

10. Svoboda. № 1.1894.

11. Svoboda. № 6. 1894.

12. Svoboda. № 9.1894.

13. Svoboda. № 13. 1894

14. Svoboda. № 23. 1894.

15. Svoboda. № 33. 1894.

16. Svoboda. № 2. 1899.

17. Svoboda. № 3. 1899.

18. Khimiak, O. (2012) Ukrainska presa na amerykanskomu kontynenti (kinets XIX pochatok XX st.) [Ukrainian press on the American continent (end of XIX-beginning of $X X$ century]. Ukrainska natsionalna ideia: realii ta perspektyvy rozvytku: Zb. nauk. pr. Lviv. Vyp. 24, 27-31.

19. Chasto, P. (2012) Vilne slovo amerykanskoi Ukrainy. [Free word of American Ukraine]. Uzhhorod: TIMPANI; Niu-York: Ukrainian Book.

УДК 94:336-057.19(477)»1920»

\title{
МАТЕРІАЛЬНЕ ЗАБЕЗПЕЧЕННЯ БЕЗРОБІТНИХ В УСРР У 1920-Х РР.
}

\section{Прилипко Руслан}

У статті проаналізовано організаційні заходи радянсько-партійного керівництва із запровадження сочіального страхування від безробіття в період НЕПу. Охарактеризовано порядок виплати допомоги безробітним, зазначено ї̈ розмір та тривалість забезпечення. Висвітлено діяльність бірж праці та страхових органів щзодо призначення матеріальної допомоги. Простежено стан виплати та динаміку розподілу допомоги безробітним серед різних професійних груп. У результаті дослідження автор приходить до висновку, щьо перехід до нової економічної політики, який супроводжувався скасуванням трудової повинності та відкривав нові механізми регулювання ринку прачі через співвідношення попиту та пропозииії на робочу силу, позначився масовим безробіттям. Окрім кон'юнктури ринку на зростання чисельності безробітних суттєво вплинули: зменшення обсягу державної промисловості та слабкий розвиток ї̈ приватної сфери; механізація виробниџтва; військова демобілізація; аграрне переселення, пролетаризація міст тощо. Поряд з індустріальними робітниками, щзо втратили заробіток через згортання виробництва, у групу ризику потрапили некваліфіковані робітники, серед яких вагома частка припадала на жінок та молодь. 
Розробляючи заходи боротьби із безробіттям, радянські лідери були змушені взяти на озброєння всі форми захисту, вироблені світовою практикою. Серед них основну роль відіграло матеріальне забезпечення безробітних через виплату грошових допомог за рахунок коштів соціального страхування. Проте страхування безробітних тут мало класовий характер. Страхове законодавство було спрямоване переважно на забезпечення пролетарських кадрів і провадило чітку класову позицію. У більшості випадків при відмові у призначенні допомог керувалися не принципом свободи праці, а обов'язком трудової повинності на користь радянської держави. Розміри допомог з безробіття не диференціювалися залежно від розміру заробітної плати прачівника, а вираховувалися із середнього заробітку. До того ж обсяг допомог залежав від території проживання безробітних та належності їх за професіями до певних категорій працівників. Обсяг грошової допомоги залежав також від стажу безперервної роботи та членства у профспілках.

Ключові слова: соціальне страхування, нова економічна політика, страхові фонди, матеріальне забезпечення, безробітні, страхові органи.

Сучасний стан розвитку ринкової економіки в Україні вимагає вироблення дієвого механізму захисту безробітних. Важливим для розуміння сучасних форм і методів організації соціального захисту безробітних є період 20-х рр. XX ст., коли радянська держава переживала подібний досвід регулювання соціальних процесів в умовах ринкової економіки. В означений період, попри певні прорахунки, вдалося сформувати основні засади соціального захисту, які згодом були розвинуті в комплексну та цілісну систему соціально-правових інститутів.

Проблема соціального захисту безробітних у 20-ті рр. ХХ ст. знайшла часткове висвітлення у наукових дослідженнях. Наприклад, концептуальні засади історичного розвитку означеного періоду викладено у працях В. Даниленка, Г. Касьянова, С. Кульчицького, В. Марочка, А. Морозова та інших авторів. Різні аспекти соціально-економічного розвитку в умовах нової економічної політики представлено у дослідженнях О. Сушка, М. Олійника, Ю. Волосника, О. Пиріг. 3 нових концептуальних позицій до вивчення матеріально-економічного становища та соціально-побутових умов праці робітників у 1920-х рр. у своїх дослідженнях підійшли О. Трубенок, П. Кравченко, С. Куглер, Т. Ніколаюк. Питання виплати матеріальної допомоги безробітним через призму діяльності органів державного соціального страхування вивчав О. Мельничук [14]. Проблему соціального захисту робітників в контексті вивчення їхнього повсякденного життя у 1920-х рр. досліджувала О. Мовчан [15].

Метою цієї статті є висвітлення змісту, основних форм і напрямів матеріального забезпечення безробітних УСРР у 20-х рр. ХХ ст.

У дослідженні було використано комплекс історичних джерел, серед яких неопубліковані матеріали Державного архіву вищих органів влади та управління України (далі ЦДАВО України), Центрального державного архіву громадських об'єднань України (далі ЦДАГО України). У роботі також було використано статистичні джерела, нормативні акти органів державної влади, збірники страхово- 
го законодавства, матеріали періодичної преси досліджуваного періоду, зокрема журналів «Вопросы страхования», «Вестник социального обеспечения». Залучення різноманітних за характером джерел дає можливість претендувати на репрезентативність дослідження та об’єктивність його висновків.

Необхідність боротьби із безробіттям для радянської держави визначалася не лише економічними та соціальними факторами. Не менш важливу роль відігравав політичний чинник. Адже зростання масового безробіття у західноєвропейських державах розглядалося як невід'ємний атрибут капіталістичного способу життя та одна із передумов і причин здійснення соціалістичних революцій. Можливість справою, а не на словах довести спроможність держави щодо соціального захисту безробітних з'явилася у більшовиків в період НЕПу, який із впровадженням ринкових механізмів в економіці загострив проблему масового безробіття.

Розробляючи заходи боротьби з безробіттям, радянсько-партійне керівництво пересвідчилося, що єдиним виходом із ситуації в умовах складного фінансово-економічного становища держави має стати запровадження соціального страхування від безробіття [6, 287]. Законодавчо на території УСРР в період НЕПу воно було започатковане постановою РНК УСРР від 11 листопада 1921 р. Згідно 3 нормативними положеннями правом на допомогу у разі втрати роботи могли скористатися колишні наймані працівники, які підлягали соціальному страхуванню і були зареєстровані в місцевій біржі праці чи професійній спілці [22, 671].

Водночас недостатність фінансів, що знаходилися у розпорядженні страхових фондів на початковому етапі, змушувала владу обмежувати категорії осіб, які могли б претендувати на отримання допомоги. За спільною інструкцією Південбюро ВЦРПС уповноваженого наркомату праці та наркомату соціального забезпечення від 24 травня 1922 р. страхування від безробіття поширювалося лише на кваліфікованих працівників. Інші робітники та службовці могли претендувати на отримання допомоги лише після трьох років безперервного стажу роботи на підприємстві $[9,103]$. Вимога стажу не стосувалася інвалідів IV-VI груп перед призначенням пенсії через інвалідність, осіб розумової праці високої кваліфікації (агрономів, вчителів, інженерів, педагогів) [21, 147]. За інструкцією Головного управління соціального страхування УСРР від 18 червня 1923 р. під опіку соцстраху потрапляли також такі категорії: неповнолітні, жінки із дітьми до 3 років або одинокі жінки з дітьми до 14 років, демобілізовані червоноармійці. За правилами ВУРСС від 14 грудня 1927 р. обов'язковою вимогою для отримання статусу безробітного було членство у профспілках $[20,21]$.

У період суцільної колективізації право отримувати допомогу з безробіття за рахунок страхових коштів було надане й окремим категоріям сільськогоспо- 
дарських робітників. Передусім це стосувалося найманих працівників селянських господарств промислового типу та колгоспів. Допомога при цьому виплачувалася лише тим, хто не мав власного господарства [11, 17-18]. Звісно, такий крок влади переслідував насамперед політичну мету, основним завданням якої було створення розшарування серед сільських товаровиробників та примушування їх вступати до колгоспів.

Виплата допомоги безробітним здійснювалася зі спеціального страхового фонду «В», кошти до якого у вигляді страхових внесків сплачували роботодавці. Водночас внески нараховувалися на працівників, які відпрацювали на підприємстві не менше 12 днів. Визначення розмірів внесків покладалося на союзне керівництво соцстраху і затверджувалося постановами ЦВК та РНК СРСР, які дублювалися в союзних республіках. Ставки внесків не були постійними і протягом 1920-х рр. неодноразово змінювалися. Спочатку за постановою РНК УСРР від 10 лютого 1922 р. їхній розмір визначався на рівні 2,5 \% від фонду заробітної плати, а з 1 березня 1923 р. для підприємств усіх форм власності і незалежно від ступеня шкідливості та небезпеки був знижений до 2 \%. Крім того, протягом 1922-1926 pр. фонд для виплати допомоги безробітним поповнювався за рахунок штрафів за порушення чинного трудового законодавства $[2,8]$.

Прагнучи перекласти фінансовий тягар виплат на приватні підприємства, за рекомендацією радянсько-партійного керівництва, органи соцстраху нерідко встановлювали пільгові тарифи для державних підприємств, установ, організацій на рівні $17 \%$ [25, 114]. Зокрема, у першій половині 1920-х pр. із великих державних промислових підприємств УСРР за пільговими ставками сплачували внески: 2 заводи тресту «Донвугілля», 7 заводів Південного машинобудівельного тресту, 8 заводів тресту «Південьсталь», а також «Хімвугілля», «Укртрестсельмаш», «Транспорткоп», гірничі підприємства каолінового комбінату, Київський металотрест, Штерівський динамітний завод та підприємства електротехнічної промисловості. Інколи, особливо на початковому етапі, державним підприємствам, за рішенням РНК УСРР, списувалася заборгованість перед соцстрахом або надавалися кредити для сплати внесків. Подібна практика не лише відіграла роль антиреклами для інших платників внесків, але й негативно позначилася на фінансовому становищі соцстраху [27, 15 зв.].

Складний фінансовий стан фонду безпосередньо позначився і на розмірі допомоги із безробіття. За інструкцією ГУСС УСРР від 25 травня 1922 р. обсяг виплат встановлювався на рівні мінімальної заробітної плати для кваліфікованих робітників та від 1/3 до 3/4 для інших працівників. У разі нестачі коштів страхові органи могли зменшувати розмір допомоги, але не більше, ніж на чверть. Однак навіть задекларовані норми були непосильними для страхових фондів. 
Зважаючи на це, страховим касам пропонувалося виплачувати допомогу у вигляді безкоштовних гарячих обідів, видачі продуктів харчування, зарахування сплати комунальних послуг [21,32].

На законодавчому рівні розміри матеріальної допомоги із безробіття вперше були визначені у Кодексі законів про працю УСРР 1922 р. Нормативним актом передбачалася суто грошова форма ії виплати, а максимальний розмір, залежно від кваліфікації безробітного та стажу роботи, не міг перевищувати 1/6 середньої заробітної плати вказаного регіону. Пільги поширювалися на неповнолітніх і демобілізованих червоноармійців. Починаючи з 1923 р. за рішенням НКП УСРР розмір допомоги із безробіття пов'язувався із вартістю бюджетного набору (I категорія - 30 \%, II категорія - $15 \%$ ) $[16,1]$.

В умовах значної інфляції грошових знаків та росту цін на продукти харчування та промислові товари Головне управління соціального страхування було змушене час від часу перезатверджувати розміри допомог та встановлювати нові вимоги щодо їх отримання. В переважній більшості найбільші розміри допомог отримували кваліфіковані робітники, службовці радянсько-партійного апарату та демобілізовані червоноармійці. Для вказаних категорій допомога становила 1/2 вартості бюджетного набору Держплану, іншим категоріям працівників - 1/3. Залежність розміру допомоги від обсягу бюджетного набору дещо покращила становище безробітних, оскільки визначала насамперед кількість продуктів, які ті могли придбати $[26,1]$.

Визначення сталих розмірів допомог із безробіття стало можливим лише після проведення грошової реформи 1924 р. та переходу до розрахунків у червінцях. У квітні 1924 р. постановою Центрального управління соціального страхування СРСР (Цусстраху СРСР) доводилося до відома республіканських управлінь те, що допомога для першої категорії безробітних призначалася у межах 7,510 крб, для другої - 5-6,5 крб. Водночас для сільськогосподарських робітників допускалося іiі зниження на 15 \%. 3 покращенням фінансового становища соцстраху зростали і розміри допомог. Наприклад, середньомісячна допомога безробітного І категорії на початку 1923 р. становила 3-4 крб, у 1924 р. - 9 крб [5, 122]. 3 підвищенням розміру допомоги та виплати у твердій валюті безробітні фактично відмовилися від отримання ії натурою, останню пропонувалося застосовувати лише для безробітних - вихідців із селян, які не мали страхового стажу.

Для ліквідації зрівнялівки у виплаті грошових допомог безробітним у лютому 1925 р. за рішенням Союзної ради соціального страхування було визнано за доцільне при визначенні розміру матеріальної допомоги брати за основу середньомісячний заробіток працівника, встановивши його частку для безробітних першої категорії на рівні $30 \%$, другої - 20 \%. Внаслідок цього, середній 
розмір матеріальної допомоги безробітним становив: у 1925 р. - 10,17 крб; у 1926 р. - 11,69 крб; у 1927 р. - 12,83 крб [23, 105].

Нові підходи до визначення розмірів страхової допомоги були накреслені VII Всесоюзним з'їздом профспілок, який вказав на необхідність збільшення розмірів допомог для членів професійних спілок та окремих груп промислових робітників. Крім цього, постановою СРСС (травень 1927 р.) змінювався сам принцип нарахування допомог. 31 червня матеріальна допомога для безробітних вже не залежала від заробітку і стажу роботи застрахованого, а визначалася у твердій грошовій сумі для кожної категорії із врахуванням тарифної смуги, на території якої проживав безробітний. Основною метою означених нововведень було намагання влади надати переваги у забезпеченні індустріальним робітникам великих промислових міст для стимулювання майбутнього виробничого потенціалу соціалістичної економіки.

В умовах відходу від засадничих принципів НЕПу проходила подальша диференціація розмірів матеріальної допомоги з безробіття. Зокрема, НКП УСРР своїм обіжником від 29 березня 1928 р. визнав, що, залежно від тарифної смуги, безробітні 1 категорії можуть отримувати допомогу від 12 до 27 крб; другої категорії - від 9 до 20 крб; третьої - від 7 до 15,5 крб [18, 43]. Розподіл на категорії визначався соціальним статусом, професією, кваліфікацією та розміром заробітної плати. За структурою забезпечення безробітних складалося із двох частин: матеріальної допомоги із безробіття та сімейної надбавки, що виплачувалася утриманцям безробітного у розмірі від 15 до 50 \% середньомісячної заробітної плати. Щодо тривалості виплати допомоги із безробіття, то відповідно до КЗпП УСРР 1922 р. він не мав перевищувати шести місяців. Згодом постановою НКП УСРР (травень 1926 р.) для кваліфікованих робітників, демобілізованих червоноармійців, неповнолітніх та самотніх жінок із дітьми був продовжений до 9 місяців $[19,180]$.

Характеризуючи порядок виплати допомоги із безробіття, варто зазначити, що рішення про призначення допомоги приймалося колегіально за участю представників страхкаси, біржі праці та профспілок у тижневий термін з дня подачі документів. Підставою для виплати допомоги був «листок безробітного», який одночасно був і засобом контролю. Курс на соціалістичну індустріалізацію вніс певні новації у забезпечення безробітних. В нових умовах страховим органам пропонувалося посилити обслуговування пролетарських верств та відмовитися від забезпечення «випадкових елементів», тобто тих, хто мав достатній життєвий рівень. Для виявлення таких категорій пропонувалося до 1 жовтня 1927 p. провести перереєстрацію безробітних.

Незалежно від рівня забезпечення на отримання допомоги з безробіття не могли претендувати особи, позбавлені виборчих прав або ті, яким було заборо- 
нено обіймати посади в органах державної влади та місцевого самоврядування, інших громадських організацій. По суті, окрім матеріального становища безробітних, до уваги брався і соціальний статус. Законодавець передбачав і випадки позбавлення або припинення виплати допомоги з безробіття. Зокрема, безробітний позбавлявся допомоги у разі відмови від роботи, запропонованої біржею праці або нерегулярного iï відвідування чи подання неправдивих даних, що стали підставою для отримання допомоги. Із взяттям курсу на індустріальний розвиток біржі праці все частіше відмовляли або ж позбавляли допомоги безробітних. Наприклад, відповідно до постанови НКП УСРР від 21 лютого 1930 р. зареєстровані на біржі втрачали право на матеріальну допомогу у разі відмови від будь-якої запропонованої роботи, зокрема і такої, що вимагала переїзду на нове місце проживання. Окрім того, умисне сфабрикування будь-яких документів для отримання допомоги тягнуло за собою кримінальну відповідальність [4, 631].

Розкриваючи практику забезпечення безробітних матеріальною допомогою, треба зазначити, що на початковий період діяльності страхових органів у цьому напрямі суттєвий вплив мав голод, який охопив південні губернії України. Зважаючи на це, РНК УСРР прийняв рішення про виділення із особистого фонду 100 тис. крб, які мали бути компенсовані за рахунок фонду страхування у разі безробіття. Суми коштів, витрачених на забезпечення безробітних вказаних регіонів, розподілялися серед інших губерній України і використовувалися здебільшого для закупівлі хліба. Окрім того, за рахунок коштів соцстраху безробітних південних губерній направляли до будинків відпочинку [1, 42].

Якщо страхове законодавство про призначення матеріальної допомоги безробітним в Україні вступило в дію з 1 лютого 1922 р., то звіти про перші виплати безробітним надійшли до управління лише 1 травня 1922 р. Документи засвідчували забезпечення 7186 безробітних Донецької губернії та 9636 безробітних Київської губернії в обсязі третини середнього заробітку для некваліфікованих робітників та половини заробітку для кваліфікованих. В інших губернських містах обмежилися лише облаштуванням безкоштовних їдалень для безробітних за рахунок страхових коштів. Така ситуація обгрунтовувалася не лише початковим організаційним станом страхової справи, але й низьким розміром страхових внесків та їх невчасним надходженням на рахунки страхових органів. Так, на 1 жовтня 1922 р. всеукраїнський фонд від безробіття складав лише 29877855 крб (грошових знаків) $[12,11]$. Відсутність готівкових коштів змушувала органи соцстраху на початковому етапі укладати договори із підприємствами, за якими вони зобов'язувалися виплачувати допомоги своїм безробітним в рахунок взаємозаліку. Крім того, роботодавці підприємств, які забезпечували безробітних громадськими роботами, звільнялися від сплати страхових внесків, адже на цей період працюючі втрачали право на отримання допомоги. 
Для ефективності роботи органів допомоги безробітним за постановою наркомату соціального забезпечення та наркомату праці УСРР від 24 липня 1922 р. при біржах праці були створені спеціальні структури - страхові пункти. Такі органи мали відіграти координуючу роль для всіх державних установ та відомств, що ставили своїм завданням обслуговування безробітних. Серед їх функціональних обов'язків були: призначення та виплата матеріальних допомог; організація та проведення громадських робіт; житлово-комунальне та побутове забезпечення безробітних $[24,350]$.

Керівництво новими організаційними структурами на місцях здійснювалося на колегіальній основі за участю органів соцстраху, підвідділів праці та профспілок. На республіканському рівні при НКП УСРР за таким принципом створювалася всеукраїнська комісія, що підпорядковувалася наркомату соціального забезпечення. Фінансування роботи зазначених структур здійснювалося за рахунок коштів соціального страхування. Для посилення роботи з надання допомоги безробітним та залучення до цієї кампанії не лише державних, але й громадських організацій за постановою УЕН від 8 вересня 1922 р. було створено Центральний комітет боротьби із безробіттям, у розпорядження якого було передано частину коштів страхових органів. До складу комітету увійшли представники всіх відомств, які могли організаційно чи матеріально вести боротьбу із безробіттям: Наркомпраці, Південбюро ВЦСПС, Наркомшляхів, Укрраднаргоспу та інших організацій $[7,13]$.

Завдання, поставлені перед органами боротьби із безробіттям, були непростими, адже на вересень 1922 р. безробіттям в Україні було охоплено понад 90 тис. промислових робітників, що складало понад 30 \% від загальноросійського обсягу. Крім того, державної допомоги потребували і мешканці південних губерній, охоплених неврожаєм, які, шукаючи порятунку у містах, поповнювали когорти безробітних. Змальовуючи загрозливу картину зростання безробіття, голова УЕН Х. Раковський у надісланій у Москву телеграмі просив терміново перерахувати 2,5 трлн крб (грошових знаків) для поповнення фондів соціального страхування [7, 2].

Обсяг виплачених допомог безробітним УСРР за перші шість місяців практичної роботи складав 15393645 крб, що дало змогу забезпечити 8799 осіб $(9,7$ \%) переважно з промислових губерній: Донецької, Харківської, Запорізької, Кременчуцької та Катеринославської. Залежно від фінансового становища страхових органів розміри виплачених допомог по губерніях були різними: від 3 до 5 тис. у Миколаївській; від 6 до 12 тис. у Харківській; від 15 до 22 тис. у Подільській; від 12 до 60 тис. крб у Полтавській губерніях. Станом на 1 листопада 1922 р. до виплати допомоги безробітним були долучені 165 страхових кас, заснованих при біржах праці $[3,74]$. 
Підпорядкування страхових органів наркомату соціального забезпечення на початковому етапі негативно позначалося на обслуговуванні безробітних. 3iбрані страховими органами кошти, а також відпущені державою дотації не завжди використовувалися за потребами. Підприємства продовжували затримувати сплату коштів до фонду безробіття, незважаючи на запроваджений порядок щомісячного звіту перед Українською радою народного господарства. В результаті на початок 1923 р. у розпорядження фонду надійшло лише 71547777 крб, з яких було використано 21136798 (29,3 \%). На деякий час питання дефіциту фонду були частково вирішені за рахунок коштів зліквідованого комітету допомог голодуючим. 3 його ж запасів для безробітних виділялося 200 тис. пудів хліба $[17,3]$.

3 поступовим покращенням фінансового становища страхових органів зростала і кількість осіб, які бажали отримати допомогу. Якщо на початковому етапі на біржі реєструвалися переважно мешканці губернських міст, то згодом до них долучилися й інші категорії. Протягом першого операційного року частка безробітних, що звернулися за допомогою, у Волинській губернії збільшилася у два рази, майже у шість разів зросла кількість охочих отримувати матеріальну допомогу із безробіття замість пенсії $[10,28]$.

Повна фінансова звітність страхових органів за 1923-24 господарський рік вперше дала можливість оцінити обсяги забезпечення безробітних у республіканському масштабі. Протягом означеного періоду страховий фонд «В» поповнився на 4392662 крб, з яких майже 73 \% було використано на виплати допомоги. Динаміка охоплення допомогою безробітних у першій половині 1920-х рр. виглядала так: на 1 жовтня 1923 р. - 28911 осіб; 1 січня 1924 р. - 41 689; 1 квітня 1924 р. - 63 912; 1 червня 1924 р. - 49 905; 1 вересня 1924 р. - 37414 осіб. Зменшення кількості безробітних, починаючи із червня місяця обгрунтовувалося зайнятістю тимчасових та сезонних працівників, а також проведенням чергових чисток. У розрізі губерній частка осіб, що отримували допомогу з безробіття, у розрахунку на 100 осіб населення становила: в Київській губернії - 6,3; Харківській - 6,9; Катеринославській - 7,7; Одеській - 10,8 [26, 2].

Зростання обсягів виплачених допомог безробітним відбувалося переважно за рахунок кваліфікованих промислових робітників. Якщо на жовтень 1923 р. серед безробітних першої категорії допомогу отримували $26,7 \%$, то на вересень - 39,2 \%. Із загальної суми допомог безробітним у 1923-24 р. 2745899 крб, майже половина, призначалася для безробітних першої категорії. Із кожних 100 безробітних страховими органами обслуговувалися: у промисловості - 39,9; на транспорті - 19; в групі обслуговування - 22,5; осіб розумової праці - 19,8; чорноробів - 16,4 осіб. Серед професій першої категорії матеріальну допомогу 
найчастіше отримували будівельники, діловоди, металісти, текстильники, харчовики. У другій категорії були широко представлені працівники мистецтв. Переважну більшість забезпечуваних $(82,4$ \%) складали члени професійних спілок. Із республіканського фонду найбільші суми виплат були здійснені в Донецькій, Харківській, Одеській та Київській губерніях. 1924-25 господарський рік позначився зменшенням обсягів офіційного безробіття в Україні. Якщо на початок року на біржах праці було зареєстровано понад 200 тис. безробітних, то на кінець - лише 155 тис. Водночас статистика того періоду свідчить про посилення роботи страхових органів. Зокрема, кількість безробітних, які щомісяця отримували допомогу, збільшилася на 14 тис. осіб, а розмір самої допомоги зріс із 7,65 до 13,17 крб [13, 50]

Аналізуючи стан виплати допомоги безробітним за професійними групами, треба зазначити перевагу індустріальних робітників, частка яких складала 43,4 \% . Незважаючи на поступове зменшення чисельності промислових робітників на біржах праці, сума виплачених їм допомог продовжувала зростати. На другому місці перебували службовці $(33,4$ \%), на третьому - некваліфіковані робітники (21,2 \%). Найбільший відсоток осіб, що отримували матеріальну допомогу, був зафіксований серед друкарів $(70,2)$, хіміків $(67,0)$ та металургів $(55,5)$. Як і раніше перевага у забезпеченні надавалася членам профспілок. Якщо на 1 жовтня 1927 р. вони складали 89,6 \%, то на 1 жовтня 1928 р. - 91,3\%, а на 1 жовтня 1929 р. - 93,6 \% усіх забезпечуваних. У розрахунку на 100 безробітних грошову допомогу отримували 54 чоловіки, 27 жінок і 19 підлітків. Загальний обсяг виплачених безробітним страхових коштів складав: у 1925-26 pp. - 10596621 крб; 1926-27 pp. - 12384504 крб; 1927-28 pp. - 16958027 крб. Питома вага витрат у бюджеті соцстраху збільшилася з 12,8 до $15,9 \%$, а частка охоплених допомогою офіційно зареєстрованих безробітних в УСРР з 1923 р. до 1929 р. зросла із 16 до $70 \%[8,55]$.

Подана нижче таблиця дає можливість простежити динаміку розподілу допомоги безробітним серед різних професійних груп.

Таблиия 1

Розподіл грошової допомоги безробітним у 1923-1929 pp. (\%) $[14,176]$

\begin{tabular}{|l|c|c|c|c|c|c|c|}
\hline \multicolumn{1}{|c|}{ Групи } & $\mathbf{1 9 2 3}$ & $\mathbf{1 9 2 4}$ & $\mathbf{1 9 2 5}$ & $\mathbf{1 9 2 6}$ & $\mathbf{1 9 2 7}$ & $\mathbf{1 9 2 8}$ & $\mathbf{1 9 2 9}$ \\
\hline Промислові робітники & 28,3 & 31,2 & 32,5 & 36,0 & 34,3 & 27,9 & 27,2 \\
\hline Будівельники & 2,2 & 2,4 & 2,3 & 3,6 & 2,5 & 12,0 & 12,5 \\
\hline Інтелігенція & 26,8 & 26,5 & 25,8 & 25,2 & 25,4 & 24,6 & 23,8 \\
\hline Інші групи & 12,2 & 10,7 & 10,6 & 11,8 & 19,1 & 18,5 & 18,2 \\
\hline Некваліфіковані робітники & 30,5 & 29,2 & 28,8 & 23,4 & 18,7 & 17,0 & 18,3 \\
\hline Разом & 100 & 100 & 100 & 100 & 100 & 100 & 100 \\
\hline
\end{tabular}


Цілком очевидною виглядає перевага індустріальних робітників, які, незважаючи на незначне зменшення, на 1929 р. становили майже третину усіх забезпечуваних. Водночас в умовах взяття курсу на модернізацію економіки суттєво скоротилася частка некваліфікованих робітників. Визначальним для зростання забезпечення будівельників було запровадження спеціальної надбавки до страхових внесків, спрямованої на розвиток промислового будівництва

Щодо розміру страхових допомог, отримуваних безробітними, то він явно не відповідав задекларованим. Якщо, наприклад, у бюджеті соцстраху на $1927-$ 28 рр. він визначався на рівні 64 \% заробітної плати, то реально, залежно від категорії та тарифної смуги, становив лише від 11 до $43 \%$. Не менш важливим $є$ те, що за постійного фактичного зростання розміру допомоги з безробіття, іiі співвідношення до заробітної плати впродовж 1924-1929 рр. залишалося майже без змін $[8,58]$. Отже, обсяг щомісячної матеріальної допомоги офіційно зареєстрованим безробітним зростав лише на індекс інфляції.

Таблиия 2

Фінансування грошової допомоги безробітним у 1923-1929 pp. (\%) [14, 177]

\begin{tabular}{|l|c|c|c|c|c|c|c|}
\hline Допомога по безробіттю & $\mathbf{1 9 2 3}$ & $\mathbf{1 9 2 4}$ & $\mathbf{1 9 2 5}$ & $\mathbf{1 9 2 6}$ & $\mathbf{1 9 2 7}$ & $\mathbf{1 9 2 8}$ & $\mathbf{1 9 2 9}$ \\
\hline від соцстраху & 16,5 & 21,7 & 44,8 & 52,7 & 56,8 & 62,4 & 64,2 \\
\hline від профспілок & 26,9 & 32,3 & 12,8 & 9,5 & 7,2 & 6,7 & 5,8 \\
\hline від соцстраху та профспілок & 32,4 & 33,5 & 38,9 & 35,5 & 33,9 & 29,1 & 28,5 \\
\hline не отримували допомоги & 24,2 & 12,5 & 3,5 & 2,3 & 2,1 & 1,8 & 1,5 \\
\hline
\end{tabular}

Аналіз внутрішньої структури грошової щомісячної основної допомоги 3 безробіття за надходженнями коштів (таблиця 2) засвідчує стрімке збільшення частки страхових коштів, тоді як доля профспілкових внесків зменшилася майже у 5 разів.

Отже, в основу матеріального забезпечення безробітних у 1920-х рр. було покладено загальнообов'язкове державне соціальне страхування, що дало змогу сформувати фінансову основу для майбутніх соціальних виплат. Якщо на початковому етапі на виплату страхової допомоги могли розраховувати лише кваліфіковані робітники, то з покращенням фінансового становища соцстраху коло таких осіб значно розширилося. Однак і надалі, з ідеологічних міркувань, державного соціального захисту були позбавлені політичні опоненти нового режиму, злісні порушники трудової дисципліни. Загалом на виплату матеріальної допомоги могли претендувати лише офіційно зареєстровані безробітні. Розміри допомоги для безробітних завжди були значно нижчими від задекларованих i займали надто скромне місце в бюджеті сім'ї безробітного. 


\begin{abstract}
The article analyzes the Soviet Communist party leadership's organizational measures for the introduction of social insurance against unemployment during the New Economic Policy period. It overviews instituted unemployment benefits, detailing their duration and amount. The article covers how financial aid provided by labor exchanges and insurance bodies. The status of payments and the dynamics of how unemployment benefits were distributed among the various occupational groups were also monitored. Based on the study's results, the author concludes that the NEP transition, which was accompanied by the abolition of the mandatory obligation to work, thus opening new mechanisms of labor market regulation through the balance of supply and demand, was marked by mass unemployment. In addition to market conditions, the increase in the number of the unemployed was significantly influenced by: decrease of state-owned industry and lackluster development of privately-owned factorues; mechanization of production; military demobilization; agrarian resettlement, proletarianization of cities, etc. Along with industrial workers, who lost their jobs due to production dwindling, unskilled workers were at risk, women and children among them.

While developing measures to combat unemployment, the Soviet leaders were forced to adopt various forms of social protection created in other countries. Among those, the financial support of the unemployed through payments, and financial benefits through social insurance funds were the primary forms. However, unemployment insurance varied depending on social class. The insurance legislation was primarily aimed at securing proletarian personnel and had a clear class bias. In most cases, the refusal to provide benefits was guided not by the principle of freedom of labor, but by the "duty" of obligation to work in favor of the Soviet state. Unemployment benefits did not differentiate depending on the employee's current wage, but were deducted from the national average. In addition, the amount of benefits depended on the territory of residence of the unemployed, and what occupational groups and categories workers belonged to. The amount of financial aid also depended on continuous work experience and union membership.
\end{abstract}

Keywords: social insurance, new economic policy, insurance funds, material security, unemployed, insurance authorities.

\title{
ДЖЕРЕЛА ТА ЛІТЕРАТУРА
}

1. Безработица и борьба с ней. Вестник соччиального обеспечения. 1922. № 1-3. C. 42 .

2. Виплати допомоги безробітним. 1921-1926 рр. ЦДАВО Украӥни. Ф. 2623. Оп. 1. Спр. 2725. 8 арк.

3. Виплати допомоги безробітним. 1922 р. ЦДАВО України. Ф. 2851. Оп. 1. Спр. 33.88 арк.

4. Горбунов А. И., Гутерман Б. Н., Усиков А. Я. Действующее законодательство по социальному страхованию СССР и РСФСР / под ред. проф. Е. Н. Даниловой. Москва: Гострудиздат, 1930. 774 с.

5. Данский Б. Г. Социальное страхование раньше и теперь. Москва: Вопросы труда, 1926. 251 с.

6. Диденко Г. Д. Рабочий класс Украины в годы восстановления народного хозяйства (1921-1925). Киев: Изд-во АН УССР, 1962. 375 с.

7. Діяльність української економічної наради. 1922 р. ЦДАВО України. Ф. 2623. Оп. 1. Спр. 824. 28 арк. 
8. Забелин Л. В. Социальное страхование в жизни рабочего СССР. Москва: Гострудиздат, $1930.90 \mathrm{c}$.

9. Инструкция по выдаче пособий безработным из п/отдела социального страхования. Вестник сочиального обеспечения. 1922. № 5-7. С. 103.

10. Ковровский Е. Страхование безработицы на Волыни. Вопросы страхования. 1924. № 11. С. 28.

11. Койре $€$. Як страхові каси забезпечують наймитів. Харків: Держтрудвидав, 1930. $32 \mathrm{c}$.

12. Любимов Б. За полгода (Итоги социального страхования). Вестник соииального обеспечения. 1922. № 8-11. С. 11.

13. Матеріальна допомога професійним робітникам в 1920 -х рр. ЦДАВО України. Ф. 2623. Оп. 1. Спр. 1641. 72 арк.

14. Мельничук О. А. Соціальне страхування в радянській Україні (20-30-ті рр. ХХ ст.). Вінниця: «Едельвейс і К», 2009. 372 с.

15. Мовчан О. М. Повсякденне життя робітників УСРР. 1920-ті рр. Київ: Інститут історії України НАН України, 2011. 312 с.

16. Немченко Л. Никаких сбережений по фонду безработицы. Bonpocы cтрахования. 1924. № 1-2. С. 1.

17. Республіканський фонд соціального страхування. 1923 р. ЦДАВО Украӥни. Ф. 2623. Оп. 1. Спр. 1200. 50 арк.

18. Розміри допомоги безробітним. ЦДАВО Украӥни. Ф. 2851. Оп. 1. Спр. 1041. 56 арк.

19. Сборник действующего законодательства по социальному страхованию на Украине / под общей редакцией И. И. Фреймана. Харьков: «Вопросы труда», 1926. $499 \mathrm{c}$.

20. Сборник новых правил получения пособий по временной нетрудоспособности, безработице и дополнительным видам. Днепропетровск, 1927. 45 с.

21. Сборник постановлений и распоряжений по социальному страхованию. Харьков, $1923.332 \mathrm{c}$.

22. Собрание узаконений УСРР. 1921. № 23. Ст. 671.

23. Союзна рада соціального страхування 1927 р. ЦДАВО Украйни. Ф. 2851. Оп. 1. Спр. 271. 300 арк.

24. Страхові пункти УСРР. 1922 р. ЦДАВО Украӥни. Ф. 348. Оп. 1. Спр. 572. 420 арк.

25. Тарифи для державних підприємств, установ, організацій. 1922-1925 pp. ЦДАВО України. Ф. 2851. Оп. 1. Спр. 4. 135 арк.

26. Торговицкий И. Страхование безработицы в 1923/24 р. Bопросы страхования. 1925. № 6. С. 1-2. 
27. Фінансове становище соцстраху УСРР 1922-1927 рр. ЦДАГО Украӥни. Ф. 1. Оп. 20. Спр. 1895. 46 арк.

\section{References}

1. Bezrabotytsa y borba s nei (1922) [Unemployment and how to fight it] Vestnyk sotsyalnoho obespechenyia. № 1-3, 42.

2. Vyplaty dopomohy bezrobitnym. 1921-1926 rr. [Payment of unemployment benefits. 1921-1926] TsDAVO Ukrainy. F. 2623. Op. 1. Spr. 2725.

3. Vyplaty dopomohy bezrobitnym. $1922 \mathrm{r}$. [Payment of unemployment benefits. 1922] TsDAVO Ukrainy. F. 2851. Op. 1. Spr. 33.

4. Horbunov, A. Y., Huterman, B. N., Usykov, A. Ya. (1930) Deistvuiushchee zakonodatelstvo po sotsyalnomu strakhovanyiu SSSR y RSFSR [Current legislation on social insurance of the USSR and the RSFSR]. Ed. prof. E. N. Danilova. Moskva: Gostrudizdat.

5. Danskyi, B. H. (1926) Sotsyalnoe strakhovanye ranshe i teper [Social insurance before and now]. Moskva: Voprosy truda.

6. Dydenko, H. D. (1962) Rabochyi klas Ukraynы v hodы vostanovlenyia narodnoho khaziaistva (1921-1925) [The working class of Ukraine during the years of restoration of the national economy (1921-1925)]. Kyiv: Publishing House of the Academy of Sciences of the Ukrainian SSR.

7. Diialnist ukrainskoi ekonomichnoi narady. 1922 r. [Activities of the Ukrainian Economic Council. 1922]. TsDAVO Ukrainy. F. 2623. Op. 1. Spr. 824.

8. Zabelyn, L. V. (1930) Sotsyalnoe strakhovanye v zhyzny rabocheho SSSR [Social insurance in the life of a worker of the USSR]. Moskva: Hostrudyzdat.

9. Instruktsyia po vydache posobii bezrabotnym iz p/otdela sotsyalnoho strakhovanyia (1922) [Instructions for issuing unemployment benefits from the social insurance department]. Vestnyk sotsyalnoho obespechenyia. № 5-7, 103.

10. Kovrovskyi, E. (1924) Strakhovanye bezrabotitsy na Volyni [Unemployment Insurance in Volhynia]. Voprosy strakhovanyia. № 11, 28.

11. Koire, Ye. (1930) Yak strakhovi kasy zabezpechuiut naimytiv [How insurance funds support hired workers]. Kharkiv: Derzhtrudvydav.

12. Liubymov, B. (1922) Za polgoda (Itogy sotsyalnogo strakhovanyia) [For half a year (Results of social insurance)]. Vestnyk sotsyalnoho obespechenyia. № 8-11, 11.

13. Materialna dopomoha profesiinym robitnykam v 1920-kh rr. [Material Assistance to Professional Workers in the 1920s]. TsDAVO Ukrainy. F. 2623. Op. 1. Spr. 1641.

14. Melnychuk, O. A. (2009) Sotsialne strakhuvannia v radianskii Ukraini (20-30-ti rr. XX st.) [Social insurance in Soviet Ukraine (20-30's of XX century)]. Vinnytsia: «Edelveis i K». 
15. Movchan, O. M. (2011) Povsiakdenne zhyttia robitnykiv USRR. 1920-ti rr. [Everyday life of the USSR workers. 1920s]. Kyiv: Instytut istorii Ukrainy NAN Ukrainy.

16. Nemchenko, L. (1924) Nikakikh sberezheniy po fondu bezrabotitsy [No savings on the unemployment fund]. Voprosy strakhovaniya. № 1-2, 1 .

17. Respublikanskyi fond sotsialnoho strakhuvannia [Republic Social Insurance Fund]. 1923 r. TsDAVO Ukrainy. F. 2623. Op. 1. Spr. 1200.

18. Rozmiry dopomohy bezrobitnym [Amounts of assistance to the unemployed]. TsDAVO Ukrainy. F. 2851. Op. 1. Spr. 1041.

19. Sbornik deistvuiushchego zakonodatelstva po sotsialnomu strakhovaniyu na Ukraine (1926) [Collection of current legislation on social insurance in Ukraine]. Ed. I. I. Freiman. Kharkov: «Questions of Labor».

20. Sbornik novykh pravil polucheniya posobiy po vremennoy netrudosposobnosti, bezrabotitse i dopolnitelnym vidam (1927) [A collection of new rules for receiving benefits for temporary disability, unemployment and additional types]. Dnepropetrovsk.

21. Sbornik postanovleniy y rasporiazheniy po sotsialnomu strakhovaniyu (1923) [A collection of regulations and orders on social insurance]. Kharkov.

22. Sobranye uzakonenyi USRR (1921) [Collection of laws of the USSR]. № 23. Art. 671.

23. Soiuzna rada sotsialnoho strakhuvannia 1927 r. [Union Council of Social Insurance 1927]. TsDAVO Ukrainy. F. 2851. Op. 1. Spr. 271.

24. Strakhovi punkty USRR. 1922 r. [Insurance offices in the Ukrainian SSR. 1922] TsDAVO Ukrainy [Central State Archives of Supreme Bodies of Power and Government of Ukraine]. F. 348. Op. 1. Spr. 572.

25. Taryfy dlia derzhavnykh pidpryiemstv, ustanov, orhanizatsii. 1922-1925 rr. [Tariffs for state-owned enterprises, institutions and organizations. 1922-1925]. TsDAVO Ukrainy. F. 2851. Op. 1. Spr. 4.

26. Torhovytskyi, Y. (1925) Strakhovanie bezrabotitsy v 1923/24 r. [Unemployment Insurance in 1923/24]. Voprosy strakhovanyia, № 6, 1-2.

27. Finansove stanovyshche sotsstrakhu USRR 1922-1927 rr. [The financial situation of the social insurance of the Ukrainian SSR in 1922-1927]. TsDAHO Ukrainy. F. 1. Op. 20. Spr. 1895. 